\title{
CITIZEN SCIENCE AND LIBRARIES: WALTZING TOWARDS A COLLABORATION
}

\section{by Tiberius Ignat, Darlene Cavalier and Caroline Nickerson}

\begin{abstract}
The authors of this paper present context and case studies to illuminate several current policies, recommendations, and practices from the United States and Europe in support of libraries seeking to engage with citizen science, with the goal of encouraging librarians in Europe to leverage existing citizen science resources and take inspiration from successful international examples to make their libraries hubs for citizen science.
\end{abstract}

Keywords: Citizen Science; Libraries; Collaboration

\section{CITIZEN SCIENCE UND BIBLIOTHEKEN: WALZER TANZEN AUF DEM WEG ZUR ZUSAMMENARBEIT}

Zusammenfassung: Die Autor*innen dieses Beitrags präsentieren Kontext- und Fallstudien, um verschiedene aktuelle Strategien, Empfehlungen und Praktiken aus den USA und Europa zur Unterstützung von Bibliotheken zu beleuchten, die sich mit $\mathrm{Ci}$ tizen Science befassen, mit dem Ziel, Bibliothekar*innen in Europa zu ermutigen, die vorhandenen Citizen Science-Ressourcen zu nutzen und sich von erfolgreichen internationalen Beispielen inspirieren zu lassen, um ihre Bibliotheken zu einem Drehkreuz für Citizen Science zu mach

Schlagwörter: Citizen Science; Bibliotheken; Zusammenarbeit

DOI: https://doi.org/10.31263/voebm.v72i2.3047

(c) Tiberius Ignat, Darlene Cavalier, Caroline Nickerson

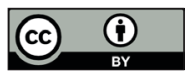

Dieses Werk ist lizenziert unter einer

Creative-Commons-Lizenz Namensnennung 4.0 International 


\section{Contents}

1. The general context of Citizen Science

2. Citizen Science: Quantified and Qualified

3. Citizen Science Defined

4. Case Study: "Libraries as Community Hubs for Citizen Science"

5. Encore!

\section{The general context of Citizen Science}

Citizen science is a developing method for enhancing the scientific endeavour, increasing scientific literacy, supporting education, and better addressing societal needs through scientific evidence. A citizen scientist shares observations or analyzes data to address a research question. The research question is typically designed by a professional scientist, although concerned or curious members of any community may initiate the research question. Though the term "citizen science" is a recent one, this form of public engagement in science has been around for as long as the field of science. Ample literature already speaks to the origin and history of citizen science as well as its successes and challenges ${ }^{1}$.

\section{Citizen Science: Quantified and Qualified}

Researchers at the University of Washington in the United States quantified the value of citizen science activities in biodiversity fields ${ }^{2}$. They surveyed 388 USA projects and found that the projects' combined 1.3-2.3 million citizen scientists provided 667 million-2.5 billion worth of labor to those projects United States Dollars, annually. For these and many other reasons, in Austria and across Europe, institutions are taking citizen science seriously. Tables 1 and 2 provide examples of European support for citizen science.

\section{Citizen Science Defined}

What is Citizen Science? It depends on whom you ask. In fact, currently there is an ongoing debate about this. Earlier this year, five Austrian authors proposed an international definition of citizen science ${ }^{3}$. Their paper triggered a flurry of online discussions and ultimately resulted in the 


\begin{tabular}{|c|c|c|}
\hline Name & Description & Online Resources \\
\hline Center for Citizen Science ${ }^{4}$ & $\begin{array}{l}\text { Established by the Federal } \\
\text { Ministry of Education, } \\
\text { Science and Research. The } \\
\text { Center supports resear- } \\
\text { chers developing citizen } \\
\text { science projects. }\end{array}$ & $\begin{array}{l}\text { https://www.zentrumfuerci- } \\
\text { tizenscience.at }\end{array}$ \\
\hline $\begin{array}{l}\text { Österreich forscht (Citizen } \\
\text { Science Network Austria) }\end{array}$ & $\begin{array}{l}\text { Established under the co- } \\
\text { ordination of the University } \\
\text { of Natural Resources Life } \\
\text { Sciences (Universität für } \\
\text { Bodenkultur). Aims to } \\
\text { improve the quality of the } \\
\text { citizen science methods } \\
\text { and processes." } 6\end{array}$ & $\begin{array}{l}\text { https://www.citizen-sci- } \\
\text { ence.at }\end{array}$ \\
\hline $\begin{array}{l}\text { Austrian Citizen Science } \\
\text { Conference }^{7}\end{array}$ & $\begin{array}{l}\text { Organized by the Citizen } \\
\text { Science Network and the } \\
\text { University of Innsbruck, the } \\
\text { fifth iteration of this con- } \\
\text { ference took place on June } \\
26-28,2019 \text { in Obergurgl. }\end{array}$ & $\begin{array}{l}\text { https://www.cs-eu.net/ } \\
\text { events/external/5th-austri- } \\
\text { an-citizen-science-confe- } \\
\text { rence-2019 }\end{array}$ \\
\hline
\end{tabular}

Tab. 1: Citizen Science in Austria 
The European Association of Research Libraries (LIBER)'s Open Science Roadmap ${ }^{9}$
This Open Science Roadmap was established by LIBER in 2018. Recommendations from this roadmap broadly endorse libraries as partners in citizen science, guiding the development of the field.

\section{LIBER Citizen Science} Working Group ${ }^{10}$

Launched in March 2019, the working group is intended to explore, among other questions, what the role of libraries will be in terms of citizen development, education, and instruction, especially relating to citizen science.

The League of European Research Universities (LERU)

\section{Science Europe}

Comprises over 23 re-
universities. They published a paper ${ }^{11}$ that analysed trends in citizen science and provided guidelines that ranged from raising awareness to developing assessments for citizen science in research funding and evaluation processes. Released a Briefing Paper on citizen science ${ }^{12}$ in 2018, endorsing the ten key principles of citizen science developed by the 'Sharing best practice and building capacity' working group of the European Citizen Science Association ${ }^{13}$.
This working group is intended to connect colleagues across Europe to explore citizen science opportunities and best practices.

Demonstrates institutional support for citizen science at the university level.
Represents major research funding and research performing organisations across Europe.

Tab. 2: Citizen Science across Europe 
publication of a response titled, "The problem with delineating narrow criteria for citizen science"14. The exchanges have been useful in reminding us of the multiple complexity of defining citizen science and, more importantly, of the critical importance of designing opportunities that provide access and power to participants, support for facilitators, and trust-worthy data for researchers.

With thousands of scientists already leading citizen science projects, and millions of participants, already participating in citizen science, we turn our attention to facilitators; in particular, libraries. Libraries offer safe spaces with access to information, resources, and communities. Similar to the waltz, a triple-time dance performed by partners dancing closely together, the collaboration of citizen science and libraries requires a close triangulation between researchers, libraries, and the public. Introducing the library as new dance partner may result in skepticism or hesitation. However, a recent case study demonstrates how libraries in the United States are finding their rhythm in the world of citizen science. Libraries in Europe can adapt this choreography. It's theirs for the taking.

\section{Case Study: "Libraries as Community Hubs for Citizen Science"15}

An ongoing project in the United States, entitled "Libraries as Community Hubs for Citizen Science," demonstrates the potential for libraries as partners in the citizen science field. With support from the Institute of Museum and Library Services, the project team for "Libraries as Community Hubs for Citizen Science," which included (1) SciStarter (an online citizen science hub), (2) Arizona State University faculty, researchers, practitioners and evaluators, (3) librarians/staff, (4) citizen science project leaders, (5) web designers/developers, and (6) advisors, collaborated to:

1. Develop and evaluate citizen science toolkits available for and through the public library partners,

2. Create associated resources to train, support, and communicate with librarians and citizen scientists

This team is now working with stakeholders to create a plan to scale the model among interested libraries, statewide and then nationwide across the United States. "Libraries as Community Hubs for Citizen Science" has enabled and continues to work with libraries to build upon their existing, successful STEM programs, capacity, and infrastructure to offer their communities sustained, engaging, and meaningful opportunities to participate 
in scientific research through citizen science. In addition to empowering librarians and their libraries to serve as leaders and community hubs for STEM learning, this project addresses known critical barriers in citizen science infrastructure, including lack of access to necessary instruments and opportunities to connect with other citizen scientists, which prohibits sustained participation in citizen science.

The initial portion of this project centered on citizen science kits, and it followed a multi-phased approach. These phases included content development and evaluation, instrument packaging, and creation of print and online resources for the toolkits. The team has provided the kits to pilot libraries and tested them to 1) learn how they are used to build or support citizen scientists at the libraries; 2) measure if and how the kits are used; and 3) identify components (tools, projects, instructions/resources) that are/are not working. The project team quickly discovered the need to support librarians and staff in learning about--and introducing-citizen science as a new concept. Staff turn-over was an issue the project team hadn't previously considered (50\% of the original partner librarians changed jobs the launch of the project). The combination of these points guided the team's approach to ensure they supported the librarians as facilitators and that they co-created kits and supporting resources (including a new build-out of a SciStarter.org/library microsite) designed to be as turn-key as possible. Recent evaluations and user-surveys demonstrate very promising results and led to national scaling up of the project. In the initial phases of the project, the team also produced the Librarian's Guide to Citizen Science ${ }^{16}$ to provide a list of case studies and resources for librarians around the world, especially centering on collective effort around and on Citizen Science Day 2019, which was on April 13, 2019. The "Libraries as Community Hubs for Citizen Science" project team was recently awarded a supplemental grant from IMLS to expand the program, in addition to new support from the National Library of Medicine (part of the National Institutes of Health) to develop programs, events, and resources to support libraries during Citizen Science Month (April 2020).

\section{Encore!}

Where might European partners start to leverage and build on the choreography of the ASU/SciStarter project? We can begin at home by combining these efforts with specific areas of needs, as outlined at the 2017 LIBER Annual Conference in Patras and later published in a journal article ${ }^{17}$ : 
- Training and evaluation on the method and protocols for volunteers and scientists.

- Infrastructure for networking, for physical spaces, for ICT and for data collection, storage, processing and preservation. This could include a single institutional point of contact for citizen science.

- Collection building for templates of protocols, data sheets, volunteers' notebooks, and checklists.

- Communication: both peer-reviewed and ordinary communication to the public.

- New roles like recruitment, marketing and advocacy around citizen science and the Third Mission of universities.

- Masterclasses and workshops ${ }^{18}$ to help librarians identify services and programs they'd need in order to support citizen science in their communities.

Any library can take the first step. This can be anything as simple as including citizen science books in a library catalog or as complex as conducting a citizen science project and answering scientific research questions. European libraries can leverage resources already existing in Europe and international examples to deftly dance in the citizen science waltz, with researchers and the public as partners.

The invitation to participate in these exercises remains open, and we hope it contributes in such a way that more libraries become hubs for citizen science activities within their communities. Please feel invited to contact the authors for more information.

Tiberius Ignat

ORCID: https://orcid.org/0000-0002-4839-2344 Scientific Knowledge Services AG E-Mail: tiberius@scientificknowledgeservices.com

Darlene Cavalier ORCID: https://orcid.org/0000-0002-6886-3289 Arizona State University / SciStarter E-Mail: Darlene.Cavalier@asu.edu

Caroline Nickerson ORCID: https://orcid.org/0000-0002-0052-9620 SciStarter E-Mail: CarolineN@SciStarter.org 
1 Cooper, Caren (2016). Citizen Science: How Ordinary People Are Changing the Face of Discovery. New York City, USA: Abrams Press.

2 Theobald, Elinore J. et al. (2015). Global change and local solutions: Tapping the unrealized potential of citizen science for biodiversity research. Biological Conservation 181, 236-244. https://doi.org/10.1016/j.biocon.2014.10.021

3 Heigl, Florian et al. (2019). Opinion: Toward an international definition of citizen science. PNAS 116(17), 8089-8092. https://doi.org/10.1073/ pnas.1903393116

4 "Center for Citizen Science". Zentrum für Citizen Science bei der OeAD (Österreichischen Austauschdienst)-GmbH, 04 July 2019. https:// www.zentrumfuercitizenscience.at/

5 "Home - Citizen-science.at". Institut für Zoologie, Department für Integrative Biologie und Biodiversitätsforschung, Universität für Bodenkultur Wien, 04 July 2019. https://www.citizen-science.at/

6 Austrian Citizen Science Conference's motto was "Borders and Transitions" (original, in German: Grenzen und Übergänge).

7 “Konferenz - Citizen-science.at". Institut für Zoologie, Department für Integrative Biologie und Biodiversitätsforschung, Universität für Bodenkultur Wien, 04 July 2019. https://www.citizen-science.at/konferenz

8 The programme can be found here: https://www.citizen-science.at/ konferenz/programm

9 “LIBER Launches Open Science Roadmap - LIBER", 10 July 2019, https://libereurope.eu/blog/2018/07/03/liber-launches-open-scienceroadmap/

10 “Explore Citizen Science: Join LIBER's Newest Working Group - LIBER", 10 July 2019. https://libereurope.eu/blog/2019/03/28/explore-citizenscience-join-libers-newest-working-group/

11 "Citizen science at universities: Trends, guidelines and recommendations | LERU”, 10 July 2019. https://www.leru.org/publications/citizen-science-at-universities-trends-guidelines-and-recommendations

12 "Science Europe Briefing Paper on Citizen Science", 10 July 2019. https://www.scienceeurope.org/wp-content/uploads/2018/07/SE_BriefingPaper_CitizenScience.pdf

13 "European Citizen Science Association | Ten Principles of Citizen Science”, 10 July 2019. https://ecsa.citizen-science.net/sites/default/files/ ecsa_ten_principles_of_citizen_science.pdf

14 Auerbach, Jeremy et al. (2019). Letter: The problem with delineating narrow criteria for citizen science. PNAS 116(31), 15336-15337. https://doi.org/10.1073/pnas.1909278116 
15 Co-authors of this paper, Darlene Cavalier and Caroline Nickerson, synthesized portions of this section of the paper from internal correspondence, evaluation reports, and related blogs.

16 A copy of the Librarian's Guide is available online here: https://s3us-west-2.amazonaws.com/orrery-media/misc/CitSci_Librarians_ Guide_02_22_r1.pdf

17 Ayris, Paul \& Ignat, Tiberius (2018). Defining the role of libraries in the Open Science landscape: a reflection on current European practice. Open Information Science 2(1), 1-22. http://doi.org/10.1515/opis2018-0001

18 Including Citizen Science Explained: Developing Citizen Science Support Service for Research Libraries, a pre-conference workshop of LIBER Annual Meeting in Dublin, June 2019. 